\title{
Mitigating Delays in Donor Funded Road Projects in Sri Lanka
}

\section{J. Jeyakanthan and A.K.W. Jayawardane}

Abstract: Delays in donor funded road projects have become inevitable, and an endemic problem in Sri Lanka hindering effective use of foreign aid granted for such projects. This paper mainly identifies significant factors causing project delays and presents strategies and recommendations to mitigate such delays.

A road map was first developed to identify the major value adding activities from inception to the completion of a road project. Twenty four projects were examined for quantitative data on time delays, in addition to a comprehensive literature survey and semi-structured interviews.

The study revealed an alarming situation that, during the implementation stage, increase in quantities had significant effect on the project time and accounted for about $56 \%$ of the delays. The results also indicated that errors and omissions in detail design, changes in specifications and scope, were the most prevalent sources of quantity increases. Further, during the tendering stage, procurement of works activities was delayed by $23 \%$ mainly due to shortcomings in contract documents and approvals from relevant agencies.

In this context, the developed process model for action to direct the implementation of donor funded road projects recommends to incorporate design constructability review as a major value adding activity in order to minimize the project delays. A rigorous approach by the executing agency (EA) is essential to make the aid more effective, accountable and transparent

Key Words: Road Construction, Delays, Donor Funded Projects, Sri Lanka

\section{Introduction}

It is generally accepted that a large number of foreign funded projects in Sri Lanka are inordinately delayed [1]. These delays are common both in building and civil engineering projects, inevitably resulting in contractual claims and increased project cost. Jayawardane and Panditha [2] quote that the delays are an indicator in assessing the success of a project and also the efficiency of all the parties involved in a project.

Assaf and Al-Hejji [3] define construction delay as the time overrun either beyond the contract date or beyond the date that the parties agreed upon for delivery of a project. Many delays occur because of failure to anticipate the problems in advance. This causes serious client dissatisfaction, loss of revenue, loss of trust and damage to prestige of the contracting parties.

Foreign aid plays a vital role in financing development projects in Sri Lanka, especially in the road sector both as reconstruction efforts after 2004 tsunami and end of a three decadelong civil conflict in 2009, in addition to general infrastructure development. The Department of
External Resources (DER) of the Ministry of Finance and Planning acts as the focal point for mobilization and co-ordination of foreign aid. Despite the fact that the project delays are common and costly in general, it becomes more significant for donor funded projects.

This study thus aims at identifying and quantifying the significant factors causing delays in road construction projects funded by Asian Development Bank (ADB), World Bank (WB) and Japan International Cooperation Agency (JICA). Timely implementation of such projects is one of the major concerns of the donors. The analysis was done at macro level.

\footnotetext{
Eng. J. Jeyakanthan, B.Sc. Eng. (Hons) (Peradeniya), MBA in Project Management (Moratuwa) 1st in Rank, Project Management Professional (USA), AMIE(Sri Lanka), MSSE(SL), MPMI(USA), Project Coordinator, UNOPS, Colombo.

Eng. (Prof.) A.K.W. Jayawardane, BSc Eng. 1st Class Hons (Moratuwa), MSc Construction (Loughborough), PhD (Loughborough), C.Eng, FIE(Sri Lanka), IntPE(SL), MSSE(SL), Senior Professor in Civil Engineering and the first NDB Bank Endowed Professor in Entrepreneurship. University of Moratuwa.
} 


\section{Literature Review}

Previous studies in project delays were mainly focusing on identifying the causes and effects of project delays during the project implementation stage. Studies in Sri Lanka include those by Jayawardane and Pandita [2] and Perera and Fernando [4] focusing on project delays at the execution stage and procurement stage respectively. Pathiranage and Halwatura [5] identified the factors influencing the duration of road constructions in Sri Lanka during the implementation stage. However, there was no attempt to analyze the project delays from the inception to its completion. Therefore, the recommendations made in these studies are not sufficient to tackle the root causes of the factors causing delays at an early stage of the project.

On the other hand, a few reports published by the DER, ADB and Institution of Engineers, Sri Lanka (IESL) have identified the effectiveness of the foreign aid utilization and the potential causes of delays in donor funded road projects in Sri Lanka and recommended steps to mitigate those delays [1] [6] [7] [8] [9] [10]. However, the contributions of those factors causing delays were not quantified. Therefore, the impact of the factors causing delays may not be seriously highlighted to the parties concerned.

\subsection{Life cycle of donor funded projects}

The life cycle of all three major donors represent quite similar activities as illustrated in Table 1, mainly from the donor's point of view [11] [12] [13].

\section{Data Collection and Analysis}

\subsection{Data Collection}

A mix of survey methods were used in this case study approach to collect the information required. This study required qualitative information to establish the incidences of delays and identify the causes of delays, and quantitative information to estimate the impact of the delays on the original project schedule.

The study aimed at having an integrated approach to analyze the projects throughout the project life cycle from inception to completion, mainly focusing on the chain of effects of the factors causing delays. The study was carried out at a macro level to identify the value incorporated in each stage and to recommend appropriate value additions to those processes in terms of delays. Twenty four donor funded road projects were surveyed as part of this research out of which seven projects had information on delays in the procurement process. Two other special cases were also considered in this study. Further, interviews were conducted with project participants. Semistructured interviews and structured surveys were the main tools used in this study.

Initially, open ended interviews were used to conduct a pilot study among the personnel involved in the donor funded road projects to understand the general perceptions of the

Table 1 - Project life cycle - Activities

\begin{tabular}{|l|l|}
\hline \multicolumn{1}{|c|}{ Project Stage } & \multicolumn{1}{c|}{ Major activities } \\
\hline Identification & $\begin{array}{l}\text { Identification of key development needs, Identification of } \\
\text { potential projects, Identification of project implementation } \\
\text { agency and appropriate staff to manage project. }\end{array}$ \\
\hline Preparation & $\begin{array}{l}\text { Feasibility studies, Fact finding mission, Determine conditions } \\
\text { required for project, Define institutional responsibility and } \\
\text { implementation plan. }\end{array}$ \\
\hline Appraisal & Review all studies, Appraisal mission. \\
\hline Loan negotiation \& Agreement & Negotiation for funds, Signing of agreement. \\
\hline Implementation & Implementation of the project, Donor supervision. \\
\hline Evaluation & Audits, Measure project outcomes against objectives, Feedback. \\
\hline
\end{tabular}


problems in various stages of the project from its inception to completion. Primary data was collected with a view to gaining an understanding of the major donor policies and procedures followed for loan agreement and procurement of goods, works and services. Qualitative data was accessed through the donor's guidelines, policy documents, instruction manuals, and various project reports available. In addition, the relevant documentation with regard to the donor funded road projects of the DER of Ministry of Finance and Planning were accessed online. Quantitative data such as the claims, progress reports, and project performance reports were accessed from the project management units (PMUs), contractors and donors.

Project and event delays were quantified through structured surveys by accessing the scheduled programmes, correspondence between client and contractors and review reports. Semi-structured interviews with experts were also held to fill in the data gaps and more specifically to gain insights into the nature of the manifestations of the causes of delays.

The factors shown in Table 2 causing delays at various phases of the project were identified through the reports of donor agencies, reports of executing agency (EA), report on the workshop held at IESL [1] and project participants. A common framework as created for data collection and categorization by drawing the road map for the entire value adding activities from inception to completion of the project (see Table 3). An attempt was then made to quantify the above factors from the project records examined for road construction.

Overall, an integrated approach was followed to quantify the delays throughout the project life cycle from inception to completion of the project in order to identify the root causes of factors causing delays.

Table 2 - Factors causing delays in donor funded projects

\begin{tabular}{|l|l|}
\hline $\mathbf{1}$ & Adverse weather \\
\hline $\mathbf{2}$ & $\begin{array}{l}\text { Ambiguous conditions \& specifications in contract } \\
\text { documents }\end{array}$ \\
\hline $\mathbf{3}$ & $\begin{array}{l}\text { Cumbersome Government policies, procurement } \\
\text { procedures }\end{array}$ \\
\hline $\mathbf{4}$ & Delays in approving subcontractor selection \\
\hline $\mathbf{5}$ & $\begin{array}{l}\text { Delays in decision making by the consultant/ } \\
\text { client }\end{array}$ \\
\hline $\mathbf{6}$ & Delay in handing over site \\
\hline $\mathbf{7}$ & Delays in land acquisition and resettlement \\
\hline $\mathbf{8}$ & Delays in obtaining licenses from authorities \\
\hline $\mathbf{9}$ & $\begin{array}{l}\text { Delays in obtaining owner approval for widening } \\
\text { the right-of-way }\end{array}$ \\
\hline $\mathbf{1 0}$ & Delays in payments to the contractor \\
\hline $\mathbf{1 1}$ & Delays in shifting utilities \\
\hline $\mathbf{1 2}$ & $\begin{array}{l}\text { Demobilizing the plant and equipment before the } \\
\text { completion of works }\end{array}$ \\
\hline $\mathbf{1 3}$ & Errors in tender drawings \\
\hline $\mathbf{1 4}$ & Errors in surveying \\
\hline $\mathbf{1 5}$ & $\begin{array}{l}\text { Inadequate and incomplete feasibility studies, site } \\
\text { investigations }\end{array}$ \\
\hline $\mathbf{1 6}$ & \begin{tabular}{l} 
Inadequate capacity in project management units \\
\hline $\mathbf{1 7}$
\end{tabular} $\begin{array}{l}\text { Inadequate participation of concerned } \\
\text { stakeholders at loan negotiations }\end{array}$ \\
\hline $\mathbf{1 8}$ & $\begin{array}{l}\text { Incomplete and improperly harmonized tender } \\
\text { documents }\end{array}$ \\
\hline $\mathbf{1 9}$ & Increase of quantities due to variations \\
\hline
\end{tabular}

\begin{tabular}{|l|l|}
\hline 20 & $\begin{array}{l}\text { Ineffective or no communication with } \\
\text { stakeholders }\end{array}$ \\
\hline $\mathbf{2 1}$ & $\begin{array}{l}\text { Insufficient supervision and attention to timely } \\
\text { implementation }\end{array}$ \\
\hline $\mathbf{2 2}$ & $\begin{array}{l}\text { Lack of experience of provincial staff and local } \\
\text { contractors with FIDIC conditions }\end{array}$ \\
\hline $\mathbf{2 3}$ & $\begin{array}{l}\text { Lack of participation of stakeholders at the early } \\
\text { stages }\end{array}$ \\
\hline $\mathbf{2 4}$ & $\begin{array}{l}\text { Lack of proactive communication between } \\
\text { contractor and consultant/ client }\end{array}$ \\
\hline $\mathbf{2 6}$ & Late possession of site by the contractors \\
\hline $\mathbf{2 7}$ & $\begin{array}{l}\text { Not identifying all the stakeholders and their } \\
\text { demands early in the project }\end{array}$ \\
\hline $\mathbf{2 8}$ & $\begin{array}{l}\text { On-the-job training that held up construction } \\
\text { work }\end{array}$ \\
\hline $\mathbf{2 9}$ & Rigidities and bureaucracy in donor agencies \\
\hline $\mathbf{3 0}$ & Scope change \\
\hline 31 & Security reasons \\
\hline 32 & Shortage of labour \\
\hline $\mathbf{3 3}$ & Shortages of quarry aggregates, bitumen \\
\hline $\mathbf{3 4}$ & Shortcomings in feasibility studies \\
\hline $\mathbf{3 5}$ & $\begin{array}{l}\text { Shortcomings on the contract documents } \\
\text { submitted }\end{array}$ \\
\hline $\mathbf{3 6}$ & Unforeseen conditions in weak soil \\
\hline
\end{tabular}


Table 3 - The road map of the donor funded road projects

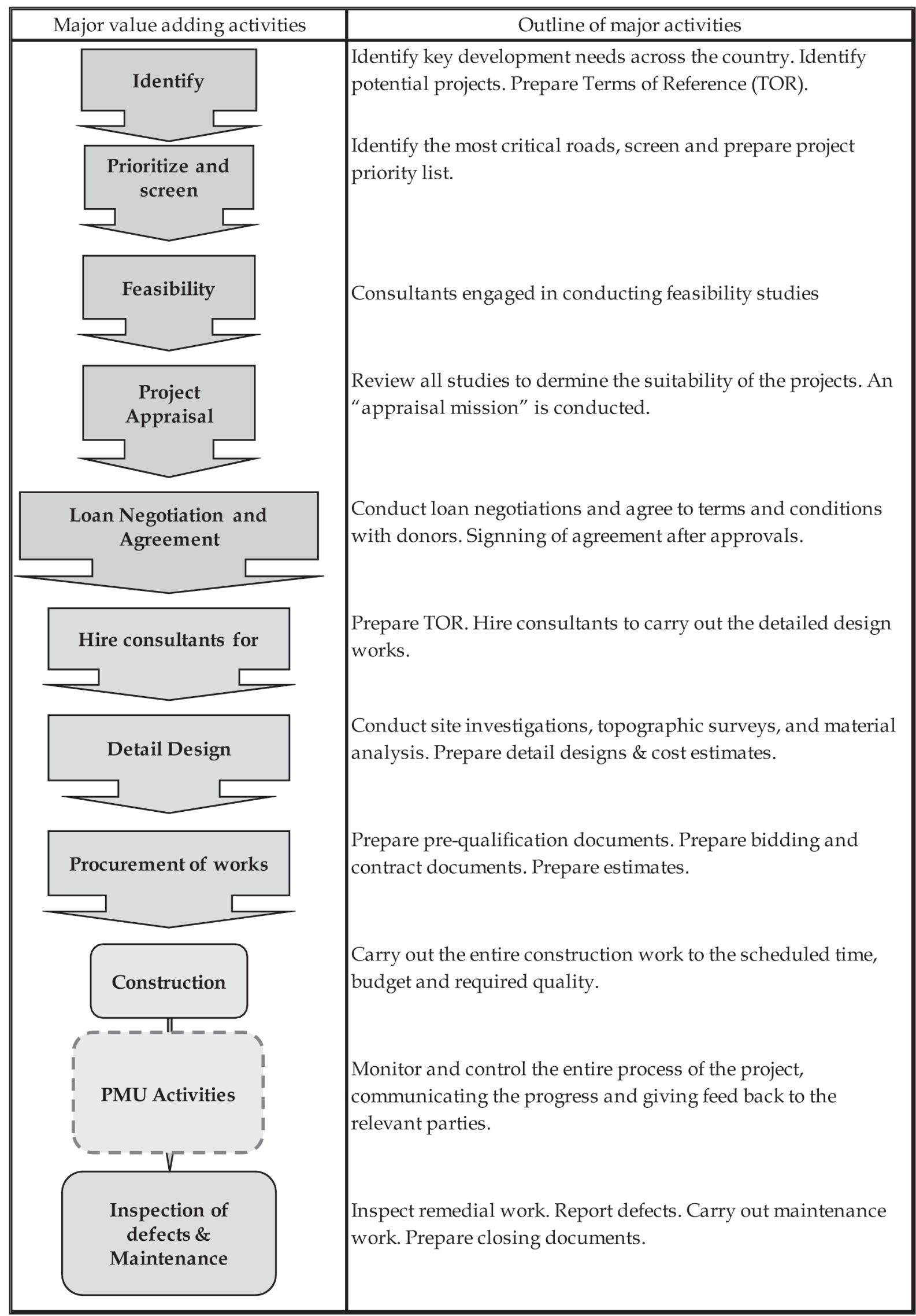




\subsection{Data analysis and discussions}

The various causes identified were categorized into major stages such as inception and feasibility, project design and tendering, project implementation, project monitoring and controlling and project closing of a road project.

\subsubsection{Inception and feasibility stage}

Significant delays were caused at this stage due to the donors and government's policies, priorities and guidelines. The delays are caused mainly due to delays in the preparation of documents for the potential projects and the non-compliance of the feasibility reports to the donor policies.

Shortcomings in feasibility studies have been one of the major root causes for delays in the design stages and consequently during the implementation stage. The feasibility study report mainly aims at satisfying the donor policies and government policies on environment, social, political and economical grounds. However, it fails to address the ground conditions and the topography in detail in many cases. Therefore, the consequences of these lapses in information are finally transferred to the implementation stage where the construction is delayed due to extra work and various other conflicts.

Another major cause for the project delays identified at this stage was the scope change ultimately causing $50 \%$ of the delay during the implementation of the projects.

Further, not identifying all the stakeholders and their demands, lack of participation of stakeholders at the early stages, inadequate participation of concerned stakeholders at loan negotiations and ineffective or no communication with them throughout the project have been some of the major factors which have led to misunderstandings and conflicts during the implementation stage causing stoppage of work.

Despite all these causes of delays, the land acquisition and resettlement issues were identified as one of the most significant causes of delays in road widening or new road projects, relevant at this stage. Almost all the interviewees accepted the above fact and admitted that this process delays the project significantly.
In practice the land acquisition and resettlement process takes long time and in one of the Road Network Improvement Projects (RNIP) it had taken almost seven years, two years more than the schedule, contributing $40 \%$ of the delay at the initial stage. The utility agencies also need to be effectively coordinated by the PMU during this period to shift the utilities underground rather than leaving the activity to be done lately, closer to the construction stage.

Another cause of delay that is relevant to be discussed at this stage is the non availability of the counterpart funds such as insurance, service charges, taxes, etc. on time. It is a common occurrence that Ministries often fail to give accurate forecasts of counterpart fund requirements for the ensuing year at the time of preparation of budget estimates for that year. The result is that there are delays in the release of funds required to meet local cost component of foreign funded projects. Nevertheless, these delays are not accounted in any projects examined.

It is also noted that, due to the changes in government policies and priorities, the time gaps between the initiation stage and the planning stage is significantly large. The project completion report of ADB [6] identifies almost three years of lapse between the project completion feasibility study for the project and the actual start of project construction. During that period, roads become further deteriorated, causing steady increases in cost above the estimates based on the conditions described in the feasibility study. This seeming paradox is common with rehabilitation projects which later results in reduction of the scope, increased cost and delay in implementation.

\subsubsection{Project design and tendering stage}

The major value adding activities at this stage were, appointment of consultants for design, preparation of detail design and procurement of contractors for construction. There were inadequate records available to analyze the process of appointment of consultants for the design in terms of delays. Moreover, there were no comments from the respondents to this study which causes delays in that process.

However, the following case was cited in the project completion report of ADB [6]. In the recruitment of the implementation consultant a nine month delay was experienced mainly 
because of an intervention by a competing bidder, questioning the eligibility of the competitor. After clarification, the ADB approved the ranking as proposed by the Executing Agency (EA). It took 332 days from the Expression of Interests (EOIs) for the EA and the selected firm to sign the contract.

It is generally accepted by the design engineers interviewed that, Inadequate and incomplete investigations have caused significant delays during the implementation stage. On the other hand, incomplete site investigations have resulted in time consuming activities like soft soil treatment later at the execution stage.

At this stage, preparation of tender documents according to the available standards has been a tedious task. Quantitative information on delays were available for only seven projects (P5 - P6, P8 - P12) out of the 24 projects examined. Overall, the delay caused in this stage was accounted from the examined projects (see Fig.1) as $23 \%$ on average. The research revealed that, Incomplete and improperly harmonized tender documents and ambiguous specifications result in repetition of work thus, causing further delay in the process. The bids submitted by the contractors were also not substantially responsive. Even the qualified bidders were called for clarification on their shortcomings on the contract documents submitted and this has been observed to be one of the most significant causes of delay in this stage. In one of the special cases examined, the condition made in the tender document such as "the contractors should possess ownership of $70 \%$ of the plant and equipment" created controversial issues and resulted in retendering causing more than double the period generally followed for procurement. In Tsunami Affected Areas Rebuilding Projects (TAARP) the procurement process was delayed by more than $100 \%$ of the planned duration due to improperly harmonized tender documents.

Overall, $68 \%$ of the delays were caused due to the shortcomings in the contract documents and $32 \%$ of delays were due to the approvals of authorities such as Cabinet Appointed Procurement Committee (CAPC) and donor (see Fig. 2).

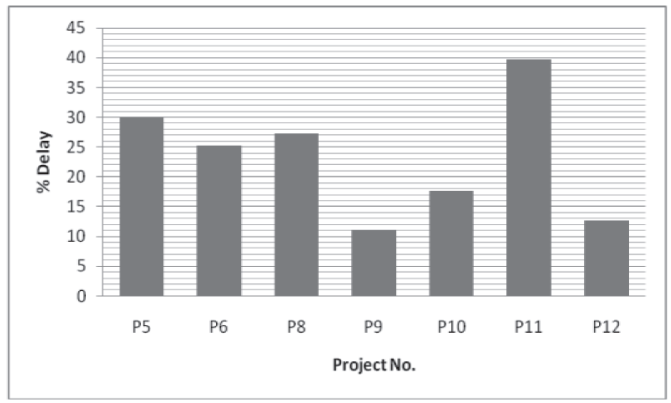

Figure 1 - Design and tendering stage delay as a percentage of original duration

The overall results indicate that, the root cause for the above being the incomplete and improperly harmonized tender documents, and inadequate capacity of contractors in preparing bids to the required standards.

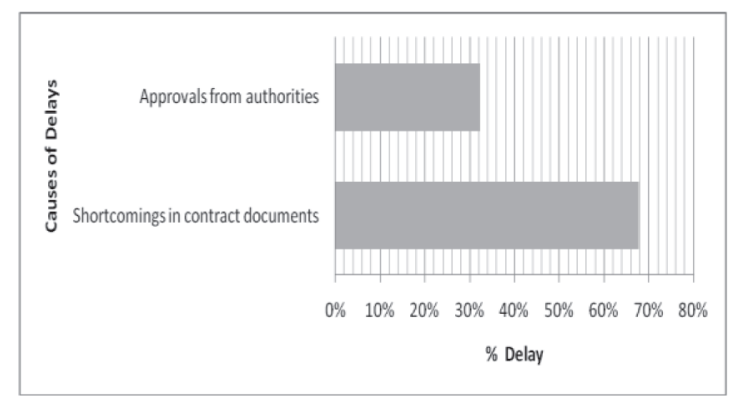

Figure 2 - Average delay percentage for causes of delays - Design and tendering stage

\subsubsection{Project implementation stage}

The actual construction of the road is carried out at this stage which is susceptible to significant delays (see Fig. 3 \& Fig. 4). The overall delay in this phase was $69 \%$ on average among the projects examined. 


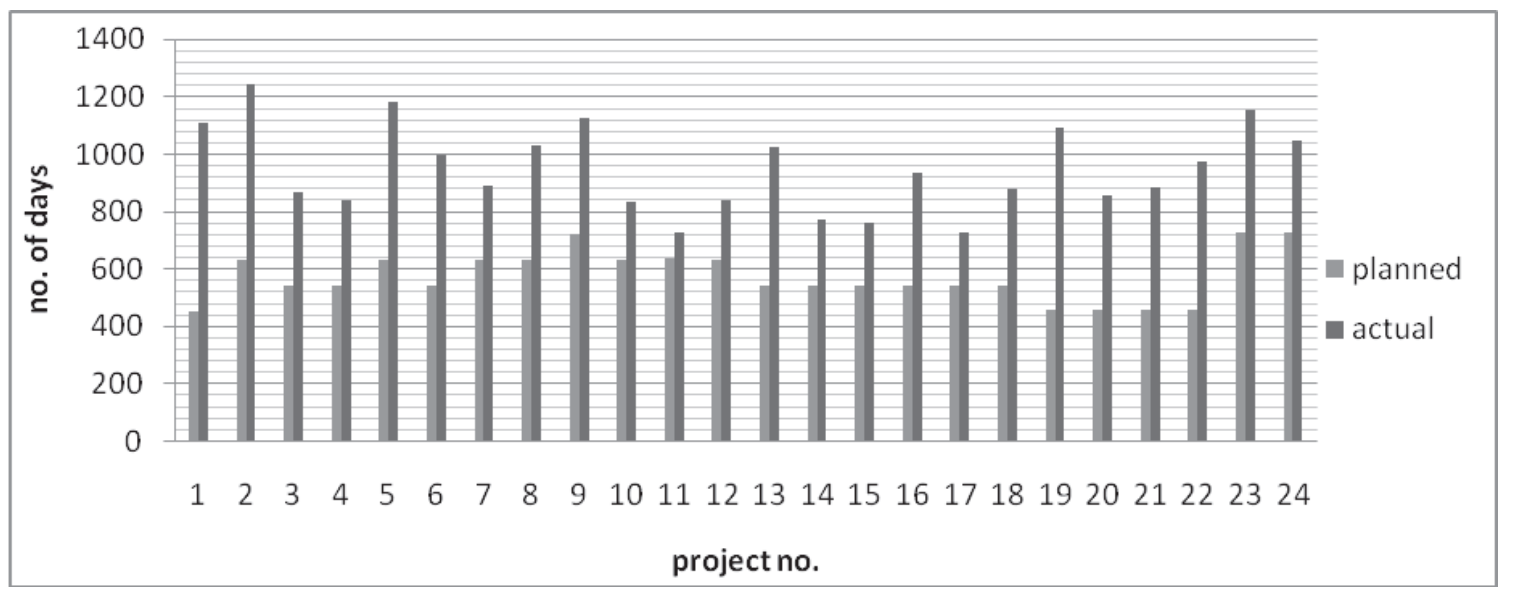

Figure 3 - Project implementation stage delay comparison

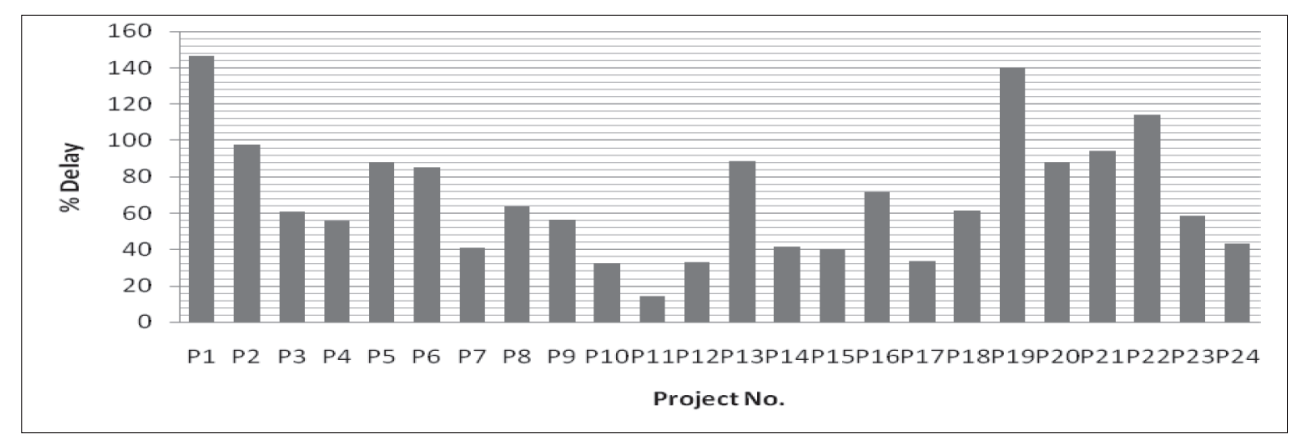

Figure 4 - Project implementation stage delay as a percentage of original duration

The overall results at the execution stage (see Fig.5) revealed that, variation/ extra work had caused $56 \%$ of delays that had affected all the projects examined quite heavily, questioning the reliability of the design details, where the ADB report [7] says "... required to prepare detailed engineering designs to enable construction quantities to be calculated with reasonable accuracy of $5 \% "$. It was observed to be the key factor to be considered in many other projects examined. The root cause for this particular delay is due to the design omissions, design errors and inadequate feasibility studies. Shortcomings in detail design create 'no information zones' for the contractor to go ahead with the construction activity smoothly. A serious review on detail designs becomes essential in order to keep the changes under control.

The project participants pointed out that, a portion of the delays caused due to variation actually had happened due to scope changes such as introduction of road furniture and changes in wearing course from Double Bituminous Surface Treatment (DBST) to Asphalt. It could not be accounted as the entire changes were recorded as variation in many cases. Shortage of bitumen had affected $50 \%$ of the projects examined contributing around $10 \%$ of the total delay on average. The adverse weather was a general cause of delay in almost all the projects examined and contributed around $6.5 \%$ of the delay.

Further, around $8 \%$ of the delay was caused due to errors in tender drawings and another $7.5 \%$ of the delay was caused due to late possession of site by the contractor. Security reasons caused around $9.5 \%$ of delays while the other reasons such as government holidays contributed $2.5 \%$ of delays which was insignificant compared to the contributions of other causes. 


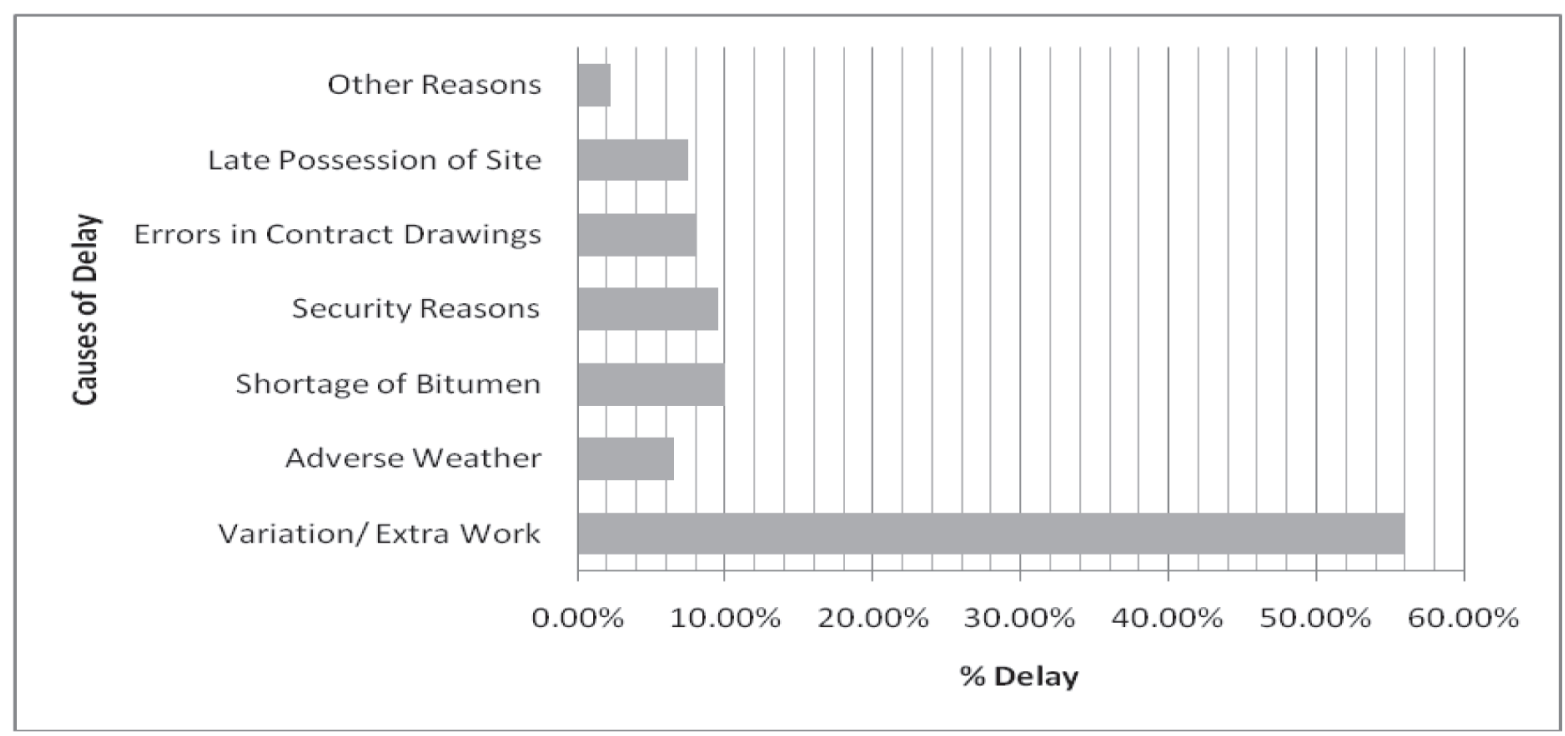

Figure 5 - Average delay percentage for causes of delays - Project implementation stage

\subsubsection{Project monitoring and controlling stage}

The project activities at this stage aim at the overall control of the activities, performed to complete the project on time, within budget and to the required quality. In this sense it becomes more appropriate for the PMUs of the respective donor funded projects to take the responsibility. It is appropriate to refer the factors causing time delays at this stage as identified by the expert panel of IESL members in 2005 for infrastructure projects in general which results in poor planning, scheduling, monitoring and contract administration. The insufficient information available from the inception of the project caused delays and contributed improper decision making throughout the project. Lack of a central information system including information on site geography, feasibility studies, design, procurement and impelmentation hinders the integration of the project from inception to closing.

\subsubsection{Project closing stage}

During the closing stage of a project, checking the as-built drawings, inspecting defects and maintenance work are the major activities carried out. However, there were no records or comments on delays registered at this stage. Generally, the period for the defects liability is one year for road projects. The lessons learned chapter of the project completion report carries vital information for planning similar projects in future.

\section{Conclusions and Recommendations}

\subsection{Conclusions}

In conclusion, the time delays in the projects examined were, generally attributable to the factors such as, inadequate feasibility studies, errors and omissions in detail design, improperly harmonized procurement documents, shortcomings in contract documents, stakeholder identification and management issues, variations and scope changes, land acquisition and resettlement, extreme weather, and shortage of bitumen.

During the project design and tendering stage, seven projects were examined. The quantitative information was available only for the tendering stage. The overall delay recorded during this stage is $23 \%$. The entire delay was due to, calling clarifications for the shortcomings in the tender documents submitted by the contractors and for necessary approvals from Technical Evaluation Committee and donor, as per the available records.

At the project implementation stage 24 projects were examined. The overall delay recorded during this stage is $69 \%$. The results revealed that, variation/ extra work had significantly affected the projects contributing $56 \%$ of the overall delay. The design omissions, design errors and inadequate feasibility studies were identified as the root causes for this particular delay. 


\subsection{Recommendations}

The executing agency (EA) has taken reasonable measures to counter the project delays. However, the results on the study do not reflect considerable amount of success in controlling delays in projects effectively. The following recommendations are made in terms of value addition and in order to mitigate the project delays in donor funded road projects based on the findings of this research.

Planning Feasibility Studies, Site Visits and Land Acquisition - The EA should revisit the time planned and budget allocated for the feasibility studies and site investigations. It is recommended that, the process requires on-site review for all projects and two such visits for complex projects. Moreover, the land acquisition and resettlement to be started immediately after getting the signs of 'go ahead' from the feasibility studies.

Stakeholder Identification and Management - The stakeholder management plays a vital role in identifying the scope of the project at an early stage and to eliminate changes in scope during the later stages of the project. Establishing a communication plan is strongly recommended to keep all the stakeholders informed on the developments.

\section{Counterpart Funding Arrangements - Inadequate resources in the Treasury to provide counterpart funding during the initial years of the project being a significant delay cause, it is recommended to design the disbursement percentages to ensure that the amount of counterpart funding required in the first two years is within a manageable amount for the Treasury.}

Project Start up and Project Management Units - In order to speed up utilization of funds, the start-up delays of the projects must be kept at minimum. Actions have to be taken to appoint Project Directors and establish Project Management Units at the very early stages of the project.

Design Constructability Review - It is strongly recommended that, the PMU has to plan design constructability reviews and make them mandatory, in order to address the design errors and omissions related delays. This should be made as a separate process prior to letting projects for biding in order to give it a serious note and should be done by competent people with interest in the project, other than the consultants involved in the detail design preparation works.

\section{Capacity Building of Contracting Parties -} Capacity building programmes need to be properly planned and implemented to all three major parties (client, consultant and contractor) and project managers with regard to the donor policies, priorities, guidelines, tender procedures, preparation of contract documents, etc. Introducing a reviewing process on contract documents prepared by the consultant, might ensure proper harmonization of tender documents. An independent procurement specialist can be appointed for this job. On the other hand, the contractors to be continually educated to build their capacity to prepare the contract documents to the required and expected standards.

"Partnering" Process - Implementing a construction partnering approach to address, among other things, improved coordination with local governments and utility authorities will improve the situation. It is recommended that, when the local entities delay a project because of utility conflicts, permitting problems, or right-of-way efforts, they should be held accountable for any resulting increase in project costs and delays. The EA should take steps to recommend the policy makers to pursue recovery of these costs where responsibility is clear cut and it is cost effective to do so.

Continuous Monitoring - Another important step to improve aid utilization is to continuously monitor the progress at different levels and give emphasis to results based budgeting as important measures to ensure speedy implementation of donor assisted projects.

Information System - Overall, it is recommended to create a better Geographic Information System (GIS) for the entire country and record all the relevant geotechnical investigation information in detail. It should be well supported by a fully fledged Information System closely aligned with project management requirement. In addition, a fully integrated Management Information System (MIS) with all geographical information starting from project data collection, screening, and modules on feasibility studies, accounting, procurement, 
and physical progress need to be developed for all components, under the leadership of the PMU.

Lessons Learnt Document - Due recognition and emphasis should be given in preparing a 'lessons learnt document' to record all the vital information that could be used when planning the next project. Specially, the problems encountered, causes of cost and time overrun, quality issues, management issues, etc. need to be recorded for future reviews.

Recommended Process Model - Finally, the developed road map (see Fig. 6) for action to direct the implementation of donor funded road projects sets out some ambitious actions prioritized in the local context. It is strongly recommended that, the stakeholder identification and design review as major value adding activities in order to improve the system, mitigating the current project delays.

It is still important for all parties in the project to carry out either the existing or new procedures with due care and diligence. More focus to be given to contract administration. A striving effort is indeed needed for the EA and the relevant parties to take a collective effort to mitigate the time delays in donor funded projects. These suggestions in fact, if correctly adopted will undoubtedly contribute significantly to keep the project delays to a minimum.

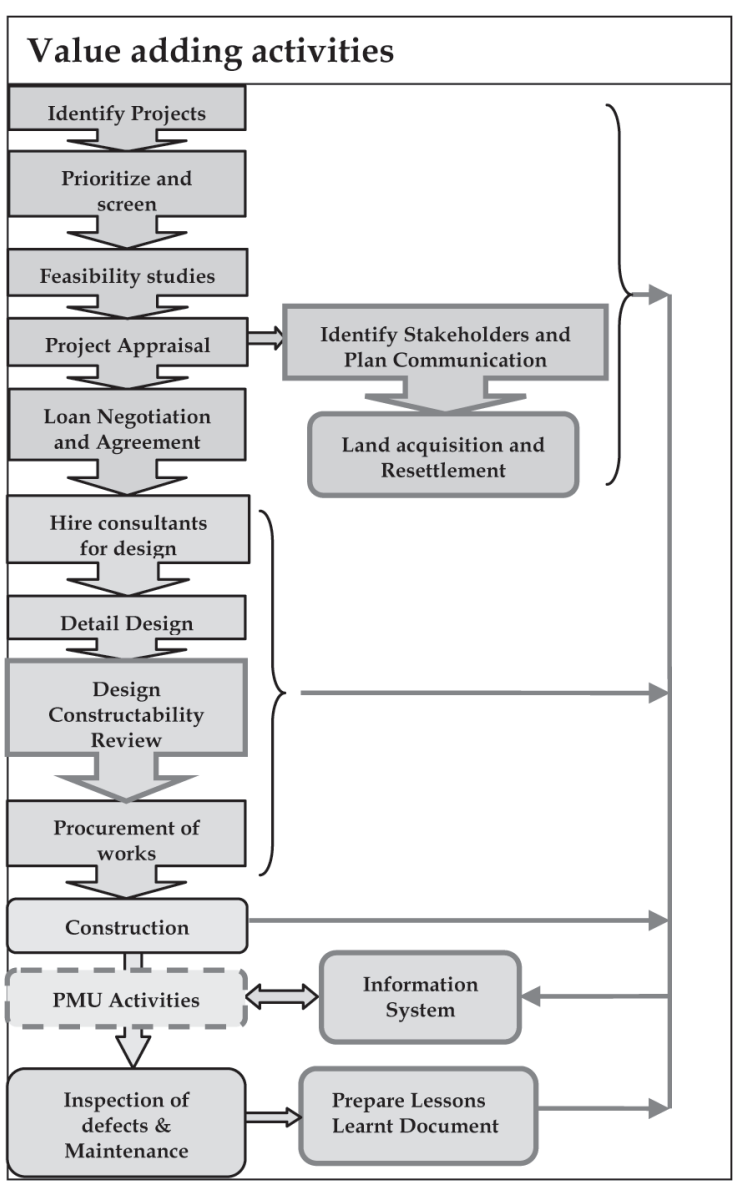

Figure 6 - The proposed road map of the donor funded road project

\section{References}

1. IESL. "Issues Related to Delays in Infrastructure Development Projects". Institution of Engineers Sri Lanka. Proceedings of a work shop held on 25, Aug. 2005 on Infrastructure Projects.

2. Jayawardane, A.K.W. and Pandita, H.G.W. "Understanding and Mitigating the Factors Affecting Construction Delays". Engineer Journal of the IESL, Vol: xxxvi, No.2, April 2003, pp. 7 - 14 .

3. Assaf, S.A., and Al-Hejji, S. "Causes of Delay in Large Construction Projects", Int J Project Management, 2006, 24 (4), pp. 349-357.

4. Perera, A.A.D.A.J. and Fernando, W.M.C. "Pre-Construction Delays in Civil Engineering Projects in Sri Lanka". M.Eng. Dissertation, University of Moratuwa, 1994. 
5. Pathiranage, Y.L. and Halwatura, R.U. "Factors Influencing the duration of Road Construction Projects in Sri Lanka". Engineer Journal of the IESL, Vol: xxxxiii, No.04, Oct. 2010, pp. $17-30$.

6. ADB. Project Completion Report: Road Sector Development Project, Sri Lanka - Dec 2009, <http://www.adb.org/Documents/PCRs /SRI/31280-SRI-PCR.pdf>, [Accessed 5 Jan 2011].

7. ADB. Technical Assistance Report: Report and Recommendation of the President to the Board of Directors on a Proposed Technical Assistance Loan to the Democratic Socialist Republic of Sri Lanka for the Road Project Preparatory Facility. Project Cycle (for Public Sector Projects) (March 2004) <http://www.adb.org/Projects/ cycle.asp>, [Accessed 13 Dec. 2010].

8. DER. Performance Report. Ministry of Finance and Planning of Sri Lanka, 2003.

9. DER. Annual Report. Ministry of Finance and Planning of Sri Lanka, 2006. < http://www.erd.gov.lk/publicweb/public
ations/ERD\%20Annual\%20Report $\% 20200$ 6\%20Final\%20Engish.pdf $>$, [Accessed 15 Jan 2011].

10. DER. Overview of Foreign Aid. Ministry of Finance and Planning of Sri Lanka, <http://www.erd.gov.lk/publicweb2007/ docs/OverviewforeignAid.pdf>, [Accessed 15 Jan. 2011].

11. ADB. Project Cycle (for Public Sector Projects) <http://www.adb.org/Projects/cycle.asp $>$, [Accessed 24 Mar. 2011].

JICA. Project Cycle, Japan International Corporation Agency (no date), <http://www.jica.go.jp/english/operatio ns/schemes/oda_loans/oda_op_info/gui dance/pdf/02_project_cycle.pdf>, [Accessed 24 Mar. 2011]

12. World Bank. How the project cycle works (no date), <http://web.worldbank.org/ WBSITE/EXTERNAL/PROJECTS/0,,conte ntMDK:20120731 menuPK:41390 pagePK :41367 piPK:51533 theSitePK:40941,00.ht ml>, [Accessed 24 Mar. 2011]. 